Article

\title{
QUALITY OF JUICES FROM DIFFERENT GRAPE CULTIVARS OBTAINED BY DISTINCT EXTRACTION SYSTEMS
}

\section{QUALIDADE DO SUCO DE DIFERENTES CULTIVARES DE UVA E SISTEMAS DE EXTRAÇÃO}

\author{
Izabel Camacho Nardello ${ }^{1, *}$, Angélica Bender ${ }^{1}$, Vinicius Caliari ${ }^{2}$, André Luiz Kulkamp de Souza ${ }^{2}$, \\ Marcelo Barbosa Malgarim ${ }^{1}$ \\ ${ }^{1}$ PPGA/UFPEL - Programa de Pós-Graduação em Agronomia/ Universidade Federal de Pelotas; Av. Eliseu Maciel, sn. Faculdade de
Agronomia Eliseu Maciel, Campus UFPel, 96160-000, Rio Grande do Sul/Capão do Leão, Brazil.
${ }^{2}$ EPAGRI - Empresa de Pesquisa Agropecuária e Extensão Rural de Santa Catarina; R. João Zardo, 2016 - Campo Experimental Videira,
89560-000, Santa Catarina/Videira, Brazil.
}

* Corresponding author: Tel.: +5553 98106-3581; e-mail: izabelnardello@gmail.com

(Received date.12.08.2021 Accepted date.26.11.2021)

\section{SUMMARY}

The objective of the present work was to evaluate the physicochemical and sensory quality of juices from different grape cultivars resulting from two extraction methods. Juices from eight grape cultivars ('Bordô', 'SCS 421 Paulina', 'BRS Carmem', 'Concord', 'BRS Cora', 'Isabel', 'Isabel Precoce' and 'BRS Violeta') were prepared using two extraction systems: an integral suquifier; an adapted heat exchanger. Physicochemical determinations, such as soluble solids, $\mathrm{pH}$, titratable acidity, ratio (relation between soluble solids and titratable acidity), reducing sugars, density, turbidity, color, total polyphenols, anthocyanins and antioxidant activity, were evaluated in the obtained juices. Sensory assessment of the juices was also carried out based on the attributes "pleasant aroma", "unpleasant aroma", "acidity", "sweetness", "balance", "body", "astringency" and "overall impression". The soluble solids content was higher when the integral suquifier was used, while total acidity was lower when the adapted heat exchanger was used for 'BRS Carmem' and 'BRS Violeta' grape cultivars. The "overall impression" of the juices showed no difference between the treatments for most grape cultivars. According to the physicochemical and antioxidant activity evaluations, the integral suquifier had superior results than the adapted heat exchanger for 'SCS 421 Paulina', 'BRS Carmem', 'Concord' and 'Isabel Precoce' grape cultivars. Sensorially, the extraction methods used did not influenced the acceptance of the juices, except for 'BRS Carmem', which showed greater appreciation when extracted by the integral suquifier, and for 'Bordô', which was more appreciated when extracted by the adapted heat exchanger method.

\section{RESUMO}

O objetivo do presente trabalho foi avaliar a qualidade físico-química e sensorial de sucos de diferentes cultivares de uvas resultantes de dois métodos de extração. Os sucos de oito cultivares de uvas ('Bordô', 'SCS 421 Paulina', 'BRS Carmem', 'Concord', 'BRS Cora', 'Isabel', 'Isabel Precoce' e 'BRS Violeta') foram preparados utilizando dois sistemas de extração: um suquificador integral; um trocador de calor adaptado. As determinações físico-químicas, incluindo sólidos solúveis, pH, acidez titulável, ratio (relação entre sólidos solúveis e acidez titulável), açúcares redutores, densidade, turbidez, cor, polifenóis totais, antocianinas e atividade antioxidante, foram avaliadas nos sucos obtidos. Foi ainda realizada a avaliação sensorial dos sucos com base nos descritores "aroma agradável", "aroma desagradável", "acidez", "doçura”, “equilíbrio", "corpo", “adstringência” e "impressão global”. O teor de sólidos solúveis foi mais elevado quando o suquificador integral foi usado, enquanto a acidez total foi menor quando o trocador de calor adaptado foi usado para as cultivares 'BRS Carmem' e 'BRS Violeta'. A “impressão geral” dos sucos não mostrou diferença entre os tratamentos para a maioria das cultivares. Relativamente às avaliações físico-químicas e à atividade antioxidante, o suquificador integral apresentou resultados superiores quando comparado com o trocador de calor adaptado para as cultivares 'SCS 421 Paulina', 'BRS Carmem', 'Concord' e 'Isabel Precoce'. Sensorialmente, os métodos de extração utilizados não influenciaram a aceitação dos sucos, exceto para 'BRS Carmem', que apresentou maior valorização quando extraído pelo suquificador integral, e para 'Bordô', que foi mais apreciado quando extraído pelo método do trocador de calor adaptado.

Keywords: Vitis labrusca, whole fruit juicer, heat extraction, physicochemical characteristics, sensory properties.

Palavras-chave: Vitis labrusca, suquificador integral, esxtração por calor, cacaracterísticas físico-químicas, características sensoriais.

\section{INTRODUCTION}

The Brazilian wine sector is an important economic segment, generating employment and income for the country in several production areas, ranging from the cultivation of grapes for fresh consumption, to those for processing (Lima et al., 2015; Zanus, 2015). In 2018 , the total cultivated area in the country was 
over 72 thousand hectares; $50 \%$ of the grapes were used for the production of wines and their derivatives and the other $50 \%$ were used for juices and their derivatives (Caliari, 2018). Data from the Brazilian Union of Vitiviniculture - UVIBRA, demonstrates the growth of grape juice production, whose commercialization has almost doubled in the domestic market in a seven-year period, reaching more than 162 million liters of grape juice sold in 2018 (UVIBRA, 2018).

The state of Santa Catarina is the second largest national producer of wines and musts, with predominance of table wines and juices. Currently, there has been an important increase in the production of grape juice in the state, which has demonstrated an inverse relationship with the production of table wines, showing a trend of converting the production of table wines to the production of grape juice (Caliari, 2018). The most economically significant wine region is located in the Alto Vale do Rio do Peixe, a region that covers several municipalities, and is characterized by the prevalence of family farming (Nodari and Frank, 2019), where the most produced grape cultivars are 'Isabel', 'Bordô' and 'Niagara branca' (Caliari, 2018).

Grape juice is obtained by extracting the liquid from the pulp and peels of the ripe grape, which when extracted is naturally enriched in organic compounds and minerals from the grape itself (Lima et al., 2015; Guerra et al., 2016). The quality of the juice is closely related to the extraction method used. The extracted juice must, in turn, keep the striking sensory characteristics of the fruit (Marcon et al., 2016). The relevant growth of grape juice production in Brazil requires studies that link the quality of the grape and the processing techniques in order to guarantee the final quality of the product (Bender $e t$ $a l .$, 2018). The phenolic composition and profile are influenced by the processing techniques used for the production of juices, mainly the time and temperature used in processing and the use of pectolytic enzymes that promote greater extraction of the constituents of the grapes (Toaldo et al., 2014; Lambri et al., 2015; Lima et al., 2015; Silva et al., 2019a).

Grape juice can be made through different processes. Traditionally, small rural producers use the extraction pan to obtain grape juice. However, this method can cause the incorporation of water into the final product, making the use of the integral product name questionable (Marcon et al., 2016; Bender et al., 2017; Bender et al., 2021). For this reason, the development of other methods that meet the legal requirements and the demand of small rural producers is needed. Therefore, the Brazilian Agricultural Research Corporation Embrapa Grape and Wine created a new system for the production of grape juice in small wine-growing properties, called integral suquifier, which aims to avoid possible incorporation of water in the final product and to be an economically viable alternative (Guerra et al., 2016; Bender et al., 2019).

In this context, the aim of this study was to assess the quality and the sensory acceptance of whole grape juice from different grape cultivars obtained through the whole juice elaboration system, called integral suquifier, compared to the heat exchanger system.

\section{MATERIALS AND METHODS}

The work was carried out at Epagri - Agricultural Research and Rural Extension Company of Santa Catarina, Videira Experimental Station (Videira, SC/Brazil), located at $27^{\circ} 02^{\prime} 27.59^{\prime \prime} \mathrm{S}, 51^{\circ} 08^{\prime} 04.73$ " $\mathrm{W}$ and 830 meters above sea level, in the 2017 harvest. According to Köppen, the region's climate is classified as humid mesothermal and mild summer (Cfb). The historical averages (1960-2016) of precipitation, average temperature and relative humidity in the months that include sprouting and harvesting (September to March) were $1.240 \mathrm{~mm}$, $19.8{ }^{\circ} \mathrm{C}$ and $73.4 \% \quad \mathrm{RH}$, respectively (EPAGRI/CIRAM, 2019).

The vineyard was installed in 2008, in the experimental field of Epagri - Videira Experimental Station, via a Y-structure conduction system using the canopy grape cultivars Vitis Labrusca 'Bordô', 'SCS 421 Paulina', 'Concord', 'Isabel' and 'Isabel Precoce', and hybrids, 'BRS Carmen', 'BRS Violet' and 'BRS Cora', grafted onto the rootstock 'VR $043-43$ ', in $3.0 \times 2.0 \mathrm{~m}$ spacing between rows and plants, respectively. All grape cultivars used in the production of juices are part of a project developed in the region of Vale do Rio do Peixe-SC.

The harvests were carried out manually in the months of January, February and March, and the juices were prepared in the experimental winery of Epagri - Videira - SC, using two extraction techniques: extraction by integral suquifier(T1) and extraction by an adapted system simulating a heat exchanger (T2).

In both treatments, mechanical de-stemming of $20 \mathrm{~kg}$ of grapes was performed with a DZ-25 machine (Enoveneta, N15, Piazzola sul Brenta, Italy) in which the grapes were previously crushed. Addition of pectolytic enzymes heat-resistant (Pectinex Ultra SP-L, Novozymes Latin America Ltda), at a concentration of $3 \mathrm{~g} / \mathrm{hL}$ (incubation temperature 45 to $50^{\circ} \mathrm{C}$ ) was made. After maceration, pressing was performed to separate the liquid (Enoveneta, idropressa 80, Piazzola sul Brenta, Italy), which was taken to the cold chamber, at a temperature of $\pm 1{ }^{\circ} \mathrm{C}$, for decanting the solid particles for 24 hours. The next day, the juice was racked and pasteurized (DVI Special Machines and Equipment Ltda, Brasil). The 
total volume of juice from each batch of samples was heated to $86^{\circ} \mathrm{C}$ and bottled at this temperature; thereafter, the bottles were cooled to $\pm 30{ }^{\circ} \mathrm{C}$ with a cold water bath, as shown in Figure 1.

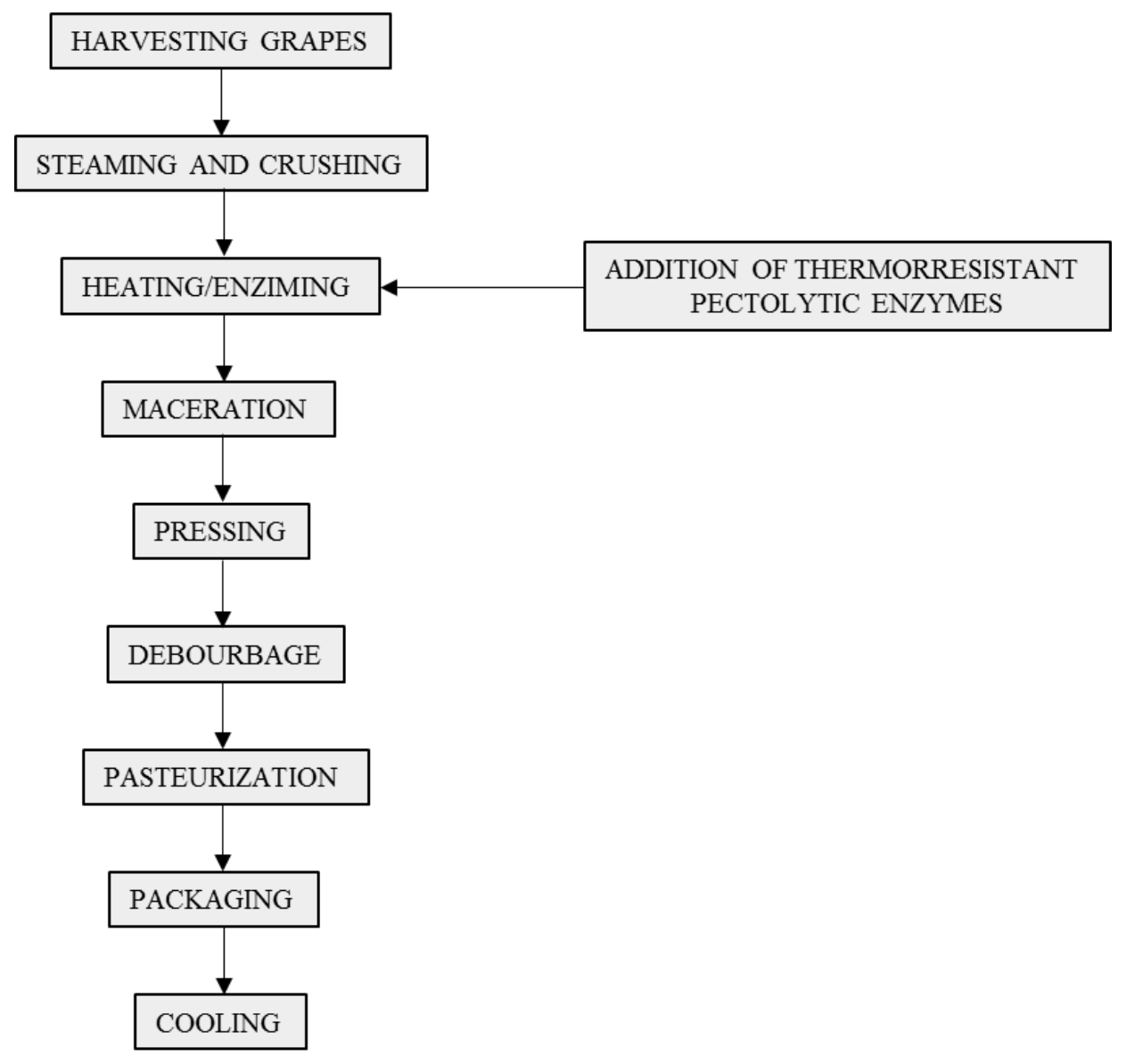

Figure 1. Grape juice production flowchart.

In Treatment 1 (T1), the berries were taken to the integral suquifier (Monofrio, integral suquifier, Brazil), equipment built in stainless steel and developed by Embrapa Uva e Vinho in 2016, which works by single-phase electricity. The heating was generated by a double jacket that contains heating liquid inside. The grapes were placed in the perforated drum located inside the equipment and homogenization was done by the equipment itself, since the drum rotates around a central axis, with a speed of $2.0 \mathrm{rpm}$. The spin takes place for one minute, remaining static for two minutes. The grapes remained inside the equipment for 1 hour, at a temperature of $\pm 50{ }^{\circ} \mathrm{C}$ for maceration, according to the recommendations of the manufacturer of the pectolytic enzymes used. The steps for preparing the juice with this new system complied with the recommendations of Guerra et al. (2016), and the equipment remained closed during the maceration period.

In Treatment 2 (T2), the berries were placed in a stainless steel container (Funilaria Estrela, Brazil) on a gas stove, for heating up to $50{ }^{\circ} \mathrm{C}$. After approximately 20 minutes of constant homogenization, the must together with the skins and seeds reached the desired temperature, being removed from the heat and kept for an hour in maceration. The equipment remained closed during the maceration period.

The juices were filled in transparent $500 \mathrm{~mL}$ glass bottles, kept at room temperature $\left( \pm 20^{\circ} \mathrm{C}\right)$ in an appropriate place for storing beverages, free of odors and excessive light, until physicochemical and sensory analyses. Five bottles of juice were used for each treatment, three of which were randomly chosen for physicochemical analyses (carried out in triplicate); each bottle represented a repetition. The remaining two bottles of juice were used in the sensory analysis.

The soluble solids (SS) content was determined in a benchtop digital refractometer with automatic temperature compensation QUIMIS $^{\circledR} \quad$ (Nova instruments, WYA -2S, Brazil) and the result were expressed in ${ }^{\circ}$ Brix. The $\mathrm{pH}$ was determined in a pHmeter Meter AD1030, and the determination of total acidity (TA) was carried out by titration of the sample (netter Toledo, 8603, China), with a standardized solution of $0.1 \mathrm{~N} \mathrm{NaOH}$, adopting, as 
the end point of the titration, $\mathrm{pH}=8.2$, and the result was expressed in $\mathrm{mEq} . \mathrm{L}^{-1}$ (Brasil, 2005). The SS/TA ratio was calculated by the quotient of SS $\left({ }^{\circ}\right.$ Brix $)$ and $\mathrm{TA}$, and was expressed in $\mathrm{g}$ of tartaric acid per 100 $\mathrm{mL}$ of juice, according to the methodology proposed by the International Organization of Vine and Wine (OIV, 2009).

The juices were also evaluated for total reducing sugars $(\mathrm{g} / \mathrm{L})$ using the DNS method described by Maldonade et al. (2013), adapted for grape juice. The density was determined with an Anton Paar glass densimeter, expressed in $\mathrm{g} / \mathrm{cm}^{3}$. The turbidity was measured in a turbidimeter (Hach $2100 \mathrm{~N}$ ) and was expressed in NTU. The color was evaluated using a spectrophotometer (Konica Minolta, CM 5, Japão): $\mathrm{L}^{*}$ (represents the lightness, ranging from fully opaque $=0$ to colorless $=100)$, $\mathrm{a}^{*}$ (takes positive values for the red hue and negative values for the green hue) and $b^{*}$ (takes positive values for yellow hue and negative values for blue hue); $\mathrm{a}^{*}$ and $\mathrm{b}^{*}$ were used in the calculations of the chroma (represents the degree of departure from gray toward pure chromatic color) and hue (represents the colors, ex. red, orange, yellow, green, etc.) of the color, obtained by the following formulas $\mathrm{C}=\left[\left(\mathrm{a}^{*}\right)^{2}+\right.$ $\left.\left(b^{*}\right)^{2}\right]^{1 / 2}$ and $\mathrm{Hue}^{\circ}=\operatorname{arc} . \tan \mathrm{b}^{*} / \mathrm{a}^{*}$, respectively, as recommended by McGuire (1992).

Total polyphenols $(\mathrm{mg} / \mathrm{L})$ were determined by the Follin-Ciocalteu colorimetric method (Singleton and Rossi, 1965), total anthocyanins (mg/L) by differential $\mathrm{pH}$ (Wrolstad, 1993), and antioxidant activity $(\mu \mathrm{mol} / \mathrm{L})$ by DPPH assay according to the methodology described by Kim et al. (2002). These analyzes were performed by spectroscopy, using a Ray Leigh spectrophotometer model UV-2601 (Beijing Ray leigh analíticas instrument co.ltd., UV 2601, China).

The sensory evaluation of the juices was performed through quantitative analysis NBR 12994 (ABNT, 1993). The intensity of the attributes was assessed on an unstructured 9-point scale (Dutcosky, 2015), anchored at the ends with the words low intensity and high intensity for "color"; little and very intense for "pleasant aroma"; imperceptible and very intense for "unpleasant aroma"; low and high concentration for "acidity" and "sweetness"; little and much for "balance" (sweetness/acidity), "body" and "astringency"; and I disliked and really liked for the "overall impression". The panel of tasters was trained in order to understanding the attributes and anchored descriptors.

The training was carried out for six months before the assessments. Taste tests (sweet, acid and bitter) were carried out with test solutions and later familiarization with samples and commercial grape juices. A group of 10 people (men and women aged from 30 to 60 years), who signed the Free and Informed Consent Term approved by the Ethics Committee of the Federal University of Pelotas, under protocol CAAE 92226218.8.0000.5317, was selected. The tasters received the samples $\left(20 \pm 1{ }^{\circ} \mathrm{C}\right)$ in wine glasses encoded with three random digits, together with the evaluation forms.

The results were submitted to analysis of variance and when a significant effect was observed, the averages values were compared by the Scott-Knott test $(\mathrm{p}<0.05)$.

\section{RESULTS AND DISCUSSION}

The physicochemical variables analyzed showed statistical significance differences and interaction between the studied treatments and the grape cultivars, except for density (data not shown) which did not present significant difference for the evaluated treatments. Comparing the soluble solids content between the juices from the grape cultivars (Table I), the highest concentrations were obtained for 'BRS Violeta' (20.47 'Brix) and 'BRS Carmem' (18.63 ${ }^{\circ}$ Brix) grape cultivars in Treatments 1 and 2, respectively, and the lowest concentrations were obtained for 'SCS 421 Paulina' grape cultivar (12.80 ${ }^{\circ}$ Brix) in T2. Such variation in the physicochemical characteristics was expected since the grape cultivars have different genetic characteristics. Camargo et al. (2008) reported that 'BRS Violeta' grape cultivar, grown under normal conditions, presented soluble solids content between $19{ }^{\circ}$ Brix and $21{ }^{\circ}$ Brix. According to Leão and Borges (2009), the 'BRS Carmem' grape cultivar had about $19{ }^{\circ}$ Brix.

Comparing the extraction methods, the soluble solids content was higher when the whole fruit juice extraction method was used (T1), regardless of the grape cultivar. This result can derive from the better homogenization of the grapes by the equipment, enhancing the tearing of the berries, and leading to greater extraction of soluble solids by pectolytic enzymes. However, the stability and activity of enzymes depend on several factors, including the characteristics of the solvent, water content, enzyme/support/rational medium ratio and the process variables involved, which can lead to different effects according to the characteristics of the system under investigation (Fadiloglu and Erkmen, 2002).

The $\mathrm{pH}$ (Table I) showed a statistical difference between all grape cultivars, with the highest value in 'BRS Violeta' (3.57) and 'BRS Carmem' (3.84) grape cultivars for $\mathrm{T} 1$ and $\mathrm{T} 2$, respectively, and the lowest value for 'Concord' grape cultivar, regardless of the treatment. The $\mathrm{pH}$ can be mainly influenced by the genetic variability of grape cultivars as well as by the processing method used to obtain the grape juice (Blouin and Peynaud, 2012). Analyzing different juices in two regions of Brazil, Santana et al. (2008) found $\mathrm{pH}$ values between 3.18 and 3.50. Silva et al. (2019b) examined concentrated grape juices and found $\mathrm{pH}$ values between 2.67 and 3.8. Although Brazilian legislation does not impose a limit value 
for $\mathrm{pH}$ in whole grape juices, this parameter is important because affect the color and taste, and also could influence the microbial activities in the foods.

Regarding the total acidity of the juices (Table I), the 'BRS Carmem' and 'BRS Violeta' grape juices had lower acidity in T2 while 'Isabel' and 'BRS Carmen' showed lower acidity in T1. However, for both treatments, the acidity of the juices complies with the legislation, which requires that the total acidity of the juices should not be less than $55 \mathrm{mEq} / \mathrm{L}$ (Brasil, 2018).

The ratio between soluble solids and titratable acidity (Table II) varied according to the grape cultivars, with the highest value observed in the 'BRS Carmem' grape cultivar in both treatments. However, comparing the treatments, it showed a higher value when submitted to T2. Conversely, 'Isabel', 'SCS 421 Paulina' and 'Concord' grape cultivars showed higher values when submitted to treatment $\mathrm{T} 1$. The relationship between soluble solids and titratable acidity, which reflects the balance between sweet and acid tastes, must comply with the ordinance 55 of July 27, 2004, that define the minimum and maximum values of 15 and 45.50 , respectively (Brasil, 2004). The juices of 'Bordô' and 'Concord' grape cultivars were below the minimum acceptable by Brazilian legislation in both treatments and that of SCS 421 Paulina grape cultivar was below the minimum acceptable by Brazilian legislation when submitted to T2. The climate of the Alto Vale do Rio do Peixe-SC region is characterized by periods of rain and cloudy days concomitant with the ripening season of the grapes, which can impair the evolution of sugars and the degradation of acids in the berries, leading to a lower ratio due to the higher acidity (Brighenti et al., 2018). In addition, the juice extraction by adapted heat exchanger (T2) proved to be less efficient in extracting soluble solids regardless of the grape cultivar, also contributing to the decrease of this parameter in the juice of the studied grape cultivars.

The content of reducing sugars (Table II) varied according to the extraction method used. The extraction method using the integral suquifier (T1) presented the highest values of reducing sugars, except for 'BRS Carmem' and 'Bordô'. The 'BRS Carmem' grape cultivar had the highest content of reducing sugars, regardless of the treatment used (T1 $201.67 \mathrm{~g} / \mathrm{L}$ and T2 $196.17 \mathrm{~g} / \mathrm{L})$. The results obtained in the present study, regardless of the grape cultivar and treatment used, are above the values found by Santana et al. (2008) in different commercial brands of American grape juice. Analyzing the behavior of the 'Concord Clone 30' grape cultivar, Bender et al. (2019) found values of $158.2 \mathrm{~g} / \mathrm{L}$ when used the whole fruit juice processor and $157.0 \mathrm{~g} / \mathrm{L}$ when used the adapted heat exchanger system.

Turbidity (Table II) was higher for most of the grape cultivars evaluated when submitted to the integral suquifier (T1), following the behavior observed in the previous parameters. Turbidity analysis indicates how turbid the juice is due to the presence of solid particles. The high turbidity values found in the present work (greater than 150 NTU) may be associated, among other factors, with the climatic conditions that occurred during the maturation/harvest period; the continuous rains that occurred at that time probably contributed to fragility of the berries and, consequently, to increase the solid particles in juices.

Table I

Physicochemical characterization of juices from different grape cultivars (Vitis labrusca and hybrids) subjected to distinct extraction methods (T1- integral suquifier, T2- adapted heat exchanger).

\begin{tabular}{ccccccc}
\hline \multirow{2}{*}{ Grape cultivars } & \multicolumn{2}{c}{ Soluble solids $\left({ }^{\circ}\right.$ Brix $)$} & \multicolumn{2}{c}{$\mathbf{p H}$} & \multicolumn{2}{c}{ Total acidity (mEq/L) } \\
\cline { 2 - 7 } & T1 & T2 & T1 & T2 & T1 & T2 \\
\hline 'BRS Carmem' & $19.70 \pm 0.17 \mathrm{bA}$ & $18.63 \pm 0.25 \mathrm{aB}$ & $3.49 \pm 0.01 \mathrm{bB}$ & $3.84 \pm 0.01 \mathrm{aA}$ & $100.50 \pm 1.48 \mathrm{fA}$ & $60.83 \pm 1.65 \mathrm{fB}$ \\
'BRS Violeta', & $20.47 \pm 0.21 \mathrm{aA}$ & $17.73 \pm 0.57 \mathrm{bB}$ & $3.57 \pm 0.01 \mathrm{aA}$ & $3.51 \pm 0.01 \mathrm{bB}$ & $128.63 \pm 2.97 \mathrm{cA}$ & $109.97 \pm 1.42 \mathrm{eB}$ \\
'BRS Cora' & $17.67 \pm 0.21 \mathrm{cA}$ & $17.20 \pm 0.00 \mathrm{cB}$ & $3.34 \pm 0.02 \mathrm{cA}$ & $3.33 \pm 0.00 \mathrm{cA}$ & $125.17 \pm 5.76 \mathrm{cB}$ & $130.34 \pm 3.20 \mathrm{cA}$ \\
'Isabel' & $17.430 .06 \pm \mathrm{cA}$ & $15.90 \pm 0.20 \mathrm{~dB}$ & $3.29 \pm 0.01 \mathrm{dA}$ & $3.29 \pm 0.01 \mathrm{dA}$ & $104.97 \pm 1.12 \mathrm{fB}$ & $118.88 \pm 5.22 \mathrm{dA}$ \\
'Isabel Precoce' & $16.93 \pm 0.06 \mathrm{dA}$ & $16.17 \pm 0.21 \mathrm{~dB}$ & $3.31 \pm 0.01 \mathrm{dA}$ & $3.27 \pm 0.01 \mathrm{eB}$ & $111.13 \pm 2.04 \mathrm{eA}$ & $110.37 \pm 2.40 \mathrm{eA}$ \\
'SCS421 Paulina' & $14.00 \pm 0.17 \mathrm{gA}$ & $12.80 \pm 0.17 \mathrm{gB}$ & $3.27 \pm 0.01 \mathrm{eA}$ & $3.26 \pm 0.01 \mathrm{eA}$ & $117.53 \pm 0.25 \mathrm{dA}$ & $118.17 \pm 0.40 \mathrm{dA}$ \\
'Bordồ & $14.57 \pm 0.06 \mathrm{fA}$ & $14.10 \pm 0.10 \mathrm{fB}$ & $3.22 \pm 0.02 \mathrm{fA}$ & $3.21 \pm 0.01 \mathrm{fA}$ & $143.70 \pm 0.26 \mathrm{bA}$ & $140.00 \pm 2.91 \mathrm{bA}$ \\
'Concord' & $16.33 \pm 0.23 \mathrm{eA}$ & $15.40 \pm 0.17 \mathrm{eB}$ & $3.08 \pm 0.00 \mathrm{gA}$ & $3.06 \pm 0.02 \mathrm{gB}$ & $158.40 \pm 3.40 \mathrm{aA}$ & $156.17 \pm 2.11 \mathrm{aA}$ \\
\hline
\end{tabular}

Means followed by the same lowercase letter in a column and uppercase letter in a row do not differ from each other by the Scott-Knott test $(\mathrm{p} \leq 0.05)$ 
Table II

Physicochemical characterization of juices from different grape cultivars (Vitis labrusca and hybrids) subjected to distinct extraction methods (T1- integral suquifier, T2- adapted heat exchanger).

\begin{tabular}{|c|c|c|c|c|c|c|}
\hline \multirow{2}{*}{ Grape cultivars } & \multicolumn{2}{|c|}{ Ratio (SS/TA) } & \multicolumn{2}{|c|}{ Reducing Sugars (g/L) } & \multicolumn{2}{|c|}{ Turbidity (NTU) } \\
\hline & T1 & T2 & T1 & $\mathbf{T 2}$ & $\mathbf{T 1}$ & $\mathbf{T 2}$ \\
\hline 'BRS Carmem' & $26.15 \pm 0.35 \mathrm{aB}$ & $40.84 \pm 1.58 \mathrm{aA}$ & $201.67 \pm 1.53 \mathrm{aA}$ & $196.17 \pm 2.52 \mathrm{aA}$ & $681.33 \pm 53.71 \mathrm{aA}$ & $264.33 \pm 78.64 \mathrm{bB}$ \\
\hline 'BRS Violeta' & $21.25 \pm 0.39 \mathrm{bA}$ & $21.54 \pm 0.83 \mathrm{bA}$ & $189.67 \pm 5.20 \mathrm{bA}$ & $174.00 \pm 2.18 \mathrm{bB}$ & $472.00 \pm 62.19 \mathrm{bA}$ & $85.30 \pm 3.97 \mathrm{bB}$ \\
\hline 'BRS Cora' & $18.83 \pm 1.01 \mathrm{dA}$ & $17.62 \pm 0.37 \mathrm{~dB}$ & $190.17 \pm 11.30 \mathrm{bA}$ & $178.33 \pm 1.53 \mathrm{bB}$ & $335.00 \pm 51.81 \mathrm{cA}$ & $156.33 \pm 1.15 b B$ \\
\hline 'Isabel' & $22.07 \pm 0.29 \mathrm{bA}$ & $17.83 \pm 0.98 \mathrm{~dB}$ & $190.50 \pm 6.87 \mathrm{bA}$ & $168.83 \pm 3.33 \mathrm{bB}$ & $286.00 \pm 34.22 \mathrm{cA}$ & $196.67 \pm 31.34 \mathrm{bA}$ \\
\hline 'Isabel Precoce' & $20.41 \pm 0.40 \mathrm{cA}$ & $19.56 \pm 0.42 \mathrm{cA}$ & $185.17 \pm 2.75 \mathrm{bA}$ & $176.00 \pm 3.61 \mathrm{bB}$ & $235.67 \pm 17.79 \mathrm{cA}$ & $157.00 \pm 10.58 \mathrm{bA}$ \\
\hline 'SCS421 Paulina' & $15.91 \pm 0.20 \mathrm{eA}$ & $14.55 \pm 0.20 \mathrm{eB}$ & $145.17 \pm 1.04 \mathrm{dA}$ & $136.50 \pm 1.32 \mathrm{eB}$ & $297.67 \pm 42.85 \mathrm{cB}$ & $540.33 \pm 95.30 \mathrm{aA}$ \\
\hline 'Bordô' & $13.49 \pm 0.05 \mathrm{fA}$ & $13.48 \pm 0.30 \mathrm{fA}$ & $146.50 \pm 3.12 \mathrm{dA}$ & $145.50 \pm 2.00 \mathrm{dA}$ & $199.00 \pm 11.27 \mathrm{cA}$ & $180.33 \pm 11.02 \mathrm{bA}$ \\
\hline 'Concord' & $13.98 \pm 0.68 \mathrm{fA}$ & $12.83 \pm 0.14 \mathrm{fB}$ & $170.00 \pm 3.61 \mathrm{cA}$ & $160.67 \pm 5.03 \mathrm{cB}$ & $772.67 \pm 26.81 \mathrm{aA}$ & $225.67 \pm 30.37 \mathrm{bB}$ \\
\hline
\end{tabular}

Means followed by the same lowercase letter in a column and uppercase letter in a row do not differ from each other by the Scott-Knott test $(\mathrm{p} \leq 0.05)$

The lightness $\left(\mathrm{L}^{*}\right)$, which could vary from $0=$ opaque to $100=$ colorless (McGuire, 1992), showed intermediate values (Table III), except for 'BRS Violet' grape cultivar, which presented $\mathrm{L}^{*}$ value of 12.38 in $\mathrm{T} 1$ and 22.05 in T2, indicating darker juices, and for the 'Isabel' and 'Isabel Precoce' grape cultivars, with the highest values in both treatments, presenting lighter juices. In general, the lightness was higher when T2 was used, showing greater transparency of the juices submitted to this treatment, contrasting what was observed by Bender et al. (2019) when analyzing the quality of Concord Clone 30 juices. In their study, the proximity to white was achieved when using the integral suquifier method.

Table III

Color characterization of juices from different grape cultivars (Vitis labrusca and hybrids) subjected to distinct extraction methods (T1- integral suquifier, T2- adapted heat exchanger).

\begin{tabular}{|c|c|c|c|c|c|c|}
\hline \multirow{2}{*}{ Grape cultivar } & \multicolumn{2}{|c|}{ Lightness (L*) } & \multicolumn{2}{|c|}{ Chroma (C) } & \multicolumn{2}{|c|}{ Hue ( ${ }^{\circ}$ Hue) } \\
\hline & $\mathbf{T 1}$ & $\mathbf{T 2}$ & $\mathbf{T 1}$ & $\mathbf{T} 2$ & T1 & $\mathbf{T} 2$ \\
\hline 'BRS Carmem' & $18.55 \pm 0.36 \mathrm{eB}$ & $44.75 \pm 1.82 \mathrm{eA}$ & $49.91 \pm 0.46 \mathrm{eA}$ & $45.36 \pm 0.33 \mathrm{~dB}$ & $4.43 \pm 1.01 \mathrm{fB}$ & $346.36 \pm 1.60 \mathrm{bA}$ \\
\hline 'BRS Violeta' & $12.38 \pm 0.03 \mathrm{fB}$ & $22.05 \pm 0.21 \mathrm{gA}$ & $47.01 \pm 0.04 \mathrm{fB}$ & $55.01 \pm 0.39 \mathrm{cA}$ & $25.41 \pm 0.03 \mathrm{cA}$ & $20.15 \pm 0.26 \mathrm{cB}$ \\
\hline 'BRS Cora' & $30.39 \pm 1.00 \mathrm{~dB}$ & $31.62 \pm 0.26 \mathrm{fA}$ & $55.67 \pm 0.39 \mathrm{bA}$ & $55.82 \pm 0.27 \mathrm{bA}$ & $9.31 \pm 0.26 \mathrm{eA}$ & $9.32 \pm 0.31 \mathrm{fA}$ \\
\hline 'Isabel' & $62.24 \pm 1.10 \mathrm{aB}$ & $67.24 \pm 0.68 \mathrm{bA}$ & $31.80 \pm 0.96 \mathrm{hA}$ & $30.46 \pm 0.28 \mathrm{gB}$ & $9.11 \pm 0.32 \mathrm{eA}$ & $5.20 \pm 0.72 \mathrm{gB}$ \\
\hline 'Isabel Precoce' & $56.51 \pm 0.03 \mathrm{bB}$ & $69.44 \pm 0.02 \mathrm{aA}$ & $39.94 \pm 0.09 \mathrm{gA}$ & $25.71 \pm 0.01 \mathrm{hB}$ & $2.47 \pm 0.06 \mathrm{fB}$ & $10.57 \pm 0.02 \mathrm{eA}$ \\
\hline 'SCS421 Paulina' & $42.67 \pm 0.37 \mathrm{cB}$ & $55.11 \pm 0.10 \mathrm{dA}$ & $53.24 \pm 0.14 \mathrm{dA}$ & $40.08 \pm 0.05 \mathrm{eB}$ & $354.82 \pm 0.68 \mathrm{bA}$ & $2.35 \pm 0.12 \mathrm{hB}$ \\
\hline 'Bordô' & $29.63 \pm 0.06 \mathrm{~dB}$ & $31.42 \pm 0.00 \mathrm{fA}$ & $58.89 \pm 0.09 \mathrm{aA}$ & $58.93 \pm 0.00 \mathrm{aA}$ & $359.25 \pm 0.10 \mathrm{aA}$ & $359.93 \pm 0.00 \mathrm{aA}$ \\
\hline 'Concord' & $42.35 \pm 0.04 \mathrm{cB}$ & $60.29 \pm 0.03 \mathrm{cA}$ & $54.69 \pm 0.06 \mathrm{cA}$ & $38.61 \pm 0.03 \mathrm{fB}$ & $17.22 \pm 0.04 \mathrm{dA}$ & $17.57 \pm 0.04 \mathrm{dA}$ \\
\hline
\end{tabular}

Means followed by the same lowercase letter in the column and uppercase letter in the row do not differ by the Scott-Knott test ( $\mathrm{p} \leq 0.05$ ).

Chroma showed differences between the grape cultivars (Table III). The highest intensity was found in 'Bordô' grape cultivar regardless of the treatment used. However, comparing the systems, the highest intensity occurred in the juices extracted by the integral suquifier (T1) for most grape cultivars, as observed by Bender et al. (2019) in juices from 'Concord Clone 30' grape cultivar. The hue in Table III reflected juices of purple red in 'Bordô' (T1 and T2), 'SCS 421 Paulina' (T1) and 'BRS Carmem' (T2) grape cultivars and red in the other grape cultivars.
The total polyphenols, anthocyanins and antioxidant activity (Table IV) revealed interaction between treatments and grape cultivars. 'BRS Violeta' grape cultivar stood out from the others by the highest levels of total polyphenols, anthocyanins and antioxidant activity. Comparing the treatments used, it was observed that the integral suquifier (T1) contributed to the greater extraction of total polyphenols and anthocyanins and higher antioxidant activity, for most of the evaluated grape cultivars. Bender et al. (2019) observed an opposite behavior with the 'Concord Clone 30' grape cultivar, in which the highest content of total polyphenols and antioxidant activity was achieved using the adapted 
heat exchanger extraction method. Silva et al. (2011) evaluated the total polyphenol index and juice color index of 'BRS Violeta' and 'Isabel Precoce', finding a significant difference between grape cultivars, claiming that 'BRS Violeta' grape cultivar has an expressive ability to infer color in juices, being an excellent choice for blending with juices from other grape cultivars with weak color.

Table IV

Phytochemical characterization of juices from different grape cultivars (Vitis labrusca and hybrids) subjected to distinct extraction methods (T1- integral suquifier, T2- adapted heat exchanger).

\begin{tabular}{ccccccc}
\hline & \multicolumn{2}{c}{ Total Polyphenols $(\mathbf{m g} / \mathrm{L})$} & \multicolumn{2}{c}{ Anthocyanins $(\mathbf{m g} / \mathrm{L})$} & \multicolumn{2}{c}{ Antioxidant activity $(\boldsymbol{\mu m o l} / \mathbf{L})$} \\
\cline { 2 - 7 } Grape cultivars & $\mathbf{T 1}$ & $\mathbf{T} 2$ & $\mathbf{T 1}$ & $\mathbf{T 2}$ & $\mathbf{T 1}$ & $\mathbf{T 2}$ \\
\hline 'BRS Carmem' & $315.78 \pm 6.76 \mathrm{bA}$ & $157.66 \pm 5.05 \mathrm{~dB}$ & $102.93 \pm 1.36 \mathrm{bA}$ & $82.37 \pm 1.98 \mathrm{bB}$ & $1.14 \pm 0.02 \mathrm{fA}$ & $0.40 \pm 0.02 \mathrm{dA}$ \\
'BRS Violeta' & $711.38 \pm 24.38 \mathrm{aA}$ & $310.00 \pm 12.34 \mathrm{aB}$ & $106.70 \pm 2.39 \mathrm{aB}$ & $136.26 \pm 3.91 \mathrm{aA}$ & $14.01 \pm 0.19 \mathrm{aA}$ & $12.74 \pm 0.17 \mathrm{aB}$ \\
'BRS Cora' & $201.18 \pm 6.21 \mathrm{dA}$ & $203.39 \pm 1.65 \mathrm{cA}$ & $36.90 \pm 0.61 \mathrm{eA}$ & $33.03 \pm 1.88 \mathrm{eB}$ & $7.80 \pm 0.09 \mathrm{cA}$ & $7.25 \pm 0.32 \mathrm{bA}$ \\
'Isabel' & $84.38 \pm 10.05 \mathrm{gA}$ & $78.04 \pm 6.68 \mathrm{fA}$ & $33.40 \pm 1.74 \mathrm{fB}$ & $36.87 \pm 1.53 \mathrm{dA}$ & $0.13 \pm 0.02 \mathrm{fA}$ & $0.11 \pm 0.00 \mathrm{dA}$ \\
'Isabel Precoce' & $122.12 \pm 2.08 \mathrm{fA}$ & $82.45 \pm 1.91 \mathrm{fB}$ & $11.46 \pm 0.63 \mathrm{hA}$ & $8.62 \pm 0.71 \mathrm{fA}$ & $3.51 \pm 0.20 \mathrm{eA}$ & $0.95 \pm 0.12 \mathrm{~dB}$ \\
'SCS421 Paulina' & $158.21 \pm 3.44 \mathrm{eA}$ & $116.61 \pm 3.60 \mathrm{eB}$ & $59.30 \pm 0.97 \mathrm{dA}$ & $37.88 \pm 1.17 \mathrm{~dB}$ & $5.95 \pm 2.33 \mathrm{dA}$ & $1.33 \pm 0.17 \mathrm{~dB}$ \\
'Bordô' & $228.46 \pm 8.32 \mathrm{cA}$ & $217.71 \pm 0.95 \mathrm{bA}$ & $77.12 \pm 3.36 \mathrm{cA}$ & $73.53 \pm 2.03 \mathrm{cB}$ & $8.72 \pm 0.10 \mathrm{bA}$ & $6.49 \pm 0.24 \mathrm{bB}$ \\
'Concord' & $222.39 \pm 1.43 \mathrm{cA}$ & $127.36 \pm 6.62 \mathrm{eB}$ & $16.14 \pm 0.13 \mathrm{gA}$ & $7.89 \pm 0.05 \mathrm{fB}$ & $7.39 \pm 0.51 \mathrm{cA}$ & $3.07 \pm 0.10 \mathrm{cB}$ \\
\hline
\end{tabular}

Averages followed by the same lowercase letter in a column and uppercase letter in a row do not differ by the Scott-Knott test ( $\mathrm{p} \leq 0.05$ ).

The sensory assessment of juices is an important indicator on the acceptance or rejection of the product in the market. The results for the attributes "color intensity", "pleasant aroma", "unpleasant aroma", "acidity" and "body", showed statistical significance only for the isolated factors of grape cultivar (Table V) and treatment (Table VI). "Sweetness" and "overall impression" showed an interaction between grape cultivar and treatment (Table VII).

Comparing the grape cultivars (Table V), 'Isabel' and 'Isabel Precoce' had the lowest scores for "color intensity", attribute confirming the results observed in the colorimeter evaluation. Bender et al. (2020) evaluated sensorially different blends of grape juices produced in integral sucker; the highest scores were assigned to the juices of 'Isabel' + 'Violeta', 'Isabel' + 'Carmem' and 'Isabel' + 'Bordo', differing from 'Isabel', 'Isabel' + 'Rúbea' and 'Isabel' + 'Cora'. The consumer's first contact with the product is the visual presentation, with emphasis on color and appearance, therefore, every product has an expected color or appearance that are associated with personal reactions of acceptance, indifference or rejection (Teixeira, 2009). Research showed that consumers had preference for grape juices with higher color intensity (Pontes et al., 2010; Borges et al., 2011; Bender et al., 2019).

In the evaluation of the "unpleasant aroma" attribute, 'BRS Cora' grape cultivar had the lowest score in absolute values, while the highest was assigned to 'BRS Violet' and 'Bordô' grape cultivars. However, no score was higher than 4 , denoting little perception of "unpleasant aroma". Aroma is one of the most complex property of the foods and beverages, whose perception depends on the chemical composition and the tasters, among other factors (Dutcosky, 2015). The "acidity" attribute had the highest score in the juices of 'Concord' and 'Bordô' grape cultivars, which is consistent with their physicochemical characteristics. The "body" attribute in beverages is perceived through the sense of touch that provides information about the texture (Dutcosky, 2015). The grape cultivars 'Isabel', followed by 'Isabel Precoce' and 'Concord' had the lowest scores for this attribute, presenting juices with less viscosity.

Comparing the treatments (Table VI), regardless of the grape cultivar, the "color intensity" attribute was higher when using the integral suquifier (T1), which also promoted higher score for the "body" attribute. Bender et al. (2019) found no difference between treatments when evaluating the 'Concord clone 30' grape cultivar. Regarding "pleasant aroma" attribute, the highest score was achieved with the method that uses adapted heat exchanger (T2), which contradicts the results of Bender et al. (2019), who found no significant difference for this variable in relation to the referred treatments.

"Sweetness" and "overall impression" attributes showed an interaction between grape cultivars and treatments (Table VII). Comparing the treatments for "sweetness", it was observed that the 'SCS 421 Paulina' submitted to T1 had the highest score. On the other hand, 'BRS Carmem' grape cultivar showed higher sweetness score when submitted to T2. There was no difference between treatments for the other grape cultivars. 
Table V

Sensory evaluation of the grape juices from different grape cultivars (Vitis labrusca and hybrids).

\begin{tabular}{|c|c|c|c|c|}
\hline Grape cultivars & Color intensity & Unpleasant aroma & Acidity & Body \\
\hline 'BRS Carmem' & $7.8 \pm 0.81 \mathrm{a}$ & $2.8 \pm 2.10 \mathrm{~b}$ & $3.7 \pm 1.52 \mathrm{c}$ & $6.1 \pm 1.62 \mathrm{a}$ \\
\hline 'BRS Violeta' & $8.1 \pm 0.71 \mathrm{a}$ & $3.8 \pm 2.62 \mathrm{a}$ & $3.3 \pm 1.39 \mathrm{c}$ & $6.9 \pm 0.91 \mathrm{a}$ \\
\hline 'BRS Cora' & $7.5 \pm 0.85 b$ & $1.5 \pm 1.48 \mathrm{~b}$ & $4.6 \pm 1.18 b$ & $6.4 \pm 0.89 a$ \\
\hline 'Isabel' & $4.9 \pm 1.51 \mathrm{~d}$ & $2.1 \pm 2.18 b$ & $4.7 \pm 1.82 \mathrm{~b}$ & $4.3 \pm 1.39 \mathrm{c}$ \\
\hline 'Isabel Precoce' & $5.2 \pm 1.55 \mathrm{~d}$ & $2.2 \pm 2.25 b$ & $3.9 \pm 1.68 \mathrm{c}$ & $5.1 \pm 1.06 \mathrm{~b}$ \\
\hline 'SCS421 Paulina' & $7.0 \pm 1.15 b$ & $2.1 \pm 1.62 b$ & $4.9 \pm 1.56 b$ & $6.2 \pm 1.62 \mathrm{a}$ \\
\hline 'Bordô' & $7.9 \pm 0.76 \mathrm{a}$ & $3.7 \pm 2.68 \mathrm{a}$ & $5.6 \pm 2.05 \mathrm{a}$ & $6.5 \pm 1.26 \mathrm{a}$ \\
\hline 'Concord' & $5.9 \pm 1.48 \mathrm{c}$ & $2.2 \pm 1.80 \mathrm{~b}$ & $5.9 \pm 1.63 \mathrm{a}$ & $5.1 \pm 1.36 b$ \\
\hline
\end{tabular}

Means followed by the same lowercase letter in a column do not differ from each other by the Scott-Knott test ( $\mathrm{p} \leq 0.05$ ).

Table VI

Sensory evaluation of the grape juices subject to different extraction methods (T1- integral suquifier, T2- adapted heat exchanger).

\begin{tabular}{|c|c|c|c|c|}
\hline Treatments & Color intensity & Pleasant aroma & Unpleasant aroma & Body \\
\hline T1 & $7.1 \pm 1.52 \mathrm{a}$ & $5.4 \pm 2.03 \mathrm{~b}$ & $3.0 \pm 2.53 \mathrm{a}$ & $6.2 \pm 1.47 \mathrm{a}$ \\
\hline $\mathbf{T 2}$ & $6.5 \pm 1.71 b$ & $6.1 \pm 1.36 \mathrm{a}$ & $2.1 \pm 1.77 \mathrm{~b}$ & $5.5 \pm 1.49 \mathrm{~b}$ \\
\hline
\end{tabular}

Means followed by the same lowercase letter in a column do not differ from each other by the Scott-Knott test ( $\mathrm{p} \leq 0.05$ ).

\section{Table VII}

Sweetness and overall impression of the grape juices subject to different extraction methods (T1- integral suquifier, T2-

\begin{tabular}{|c|c|c|c|c|}
\hline \multirow{2}{*}{ Grape cultivars } & \multicolumn{2}{|c|}{ Sweetness } & \multicolumn{2}{|c|}{ Overall Impression } \\
\hline & $\mathbf{T 1}$ & $\mathbf{T} 2$ & T1 & $\mathbf{T} 2$ \\
\hline 'BRS Carmem' & $6.3 \pm 1.29 \mathrm{aB}$ & $7.5 \pm 0.56 \mathrm{aA}$ & $6.4 \pm 1.40 \mathrm{aA}$ & $4.8 \pm 1.41 \mathrm{aB}$ \\
\hline 'BRS Violeta' & $6.6 \pm 0.82 \mathrm{aA}$ & $7.4 \pm 0.80 \mathrm{aA}$ & $4.2 \pm 2.06 \mathrm{bA}$ & $5.3 \pm 1.71 \mathrm{aA}$ \\
\hline 'BRS Cora' & $6.8 \pm 1.22 \mathrm{aA}$ & $5.8 \pm 1.54 \mathrm{bA}$ & $6.2 \pm 0.96 \mathrm{aA}$ & $6.0 \pm 1.44 \mathrm{aA}$ \\
\hline 'Isabel' & $6.4 \pm 0.76 \mathrm{aA}$ & $5.8 \pm 1.63 \mathrm{bA}$ & $4.6 \pm 1.53 \mathrm{bA}$ & $4.6 \pm 1.77 \mathrm{aA}$ \\
\hline 'Isabel Precoce' & $7.0 \pm 1.53 \mathrm{aA}$ & $6.4 \pm 1.61 \mathrm{aA}$ & $5.7 \pm 1.88 \mathrm{aA}$ & $5.4 \pm 0.93 \mathrm{aA}$ \\
\hline 'SCS421 Paulina' & $6.8 \pm 1.04 \mathrm{aA}$ & $4.6 \pm 1.61 \mathrm{bB}$ & $6.3 \pm 1.50 \mathrm{aA}$ & $5.7 \pm 1.51 \mathrm{aA}$ \\
\hline 'Bordô' & $5.2 \pm 1.46 \mathrm{aA}$ & $5.6 \pm 2.24 \mathrm{bA}$ & $3.9 \pm 2.38 \mathrm{bB}$ & $6.0 \pm 1.64 \mathrm{aA}$ \\
\hline 'Concord' & $6.0 \pm 1.25 \mathrm{aA}$ & $5.5 \pm 1.26 \mathrm{bA}$ & $5.6 \pm 1.93 \mathrm{aA}$ & $5.5 \pm 1.32 \mathrm{aA}$ \\
\hline
\end{tabular}

Means followed by the same lowercase letter in a column or uppercase letter in a row do not differ by the Scott-Knott test ( $\mathrm{p} \leq 0.05$ ).

Regarding the "overall impression" attribute, the adapted heat exchanger method (T2) promoted no differences between the grape cultivars evaluated. Comparing the treatments, 'Bordô' grape cultivars stand out, with a score lower than 4 in T1, showing slight disapproval when this grape cultivar is submitted to the whole fruit juicer. When T2 was considered, the 'BRS Carmem' grape cultivar had the lowest score, while the other grape cultivars showed no differences in relation to the treatments.

Results show that juice extraction methods affect the quality of the final product. The quality is also influenced by the grape cultivar used. In addition, the studied methods also differ in the production capacity. The heat exchanger is widely used in the production of medium or large volumes while the integral suquifier was developed for the elaboration of grape juice in micro and small properties, in order to meet the technological requirements for whole fruit juice (Guerra et al., 2016) and has proved assure the quality of grape juice.

\section{CONCLUSIONS}

The integral suquifier showed better performance than the adapted heat exchanger for 'SCS 421 Paulina', 'BRS Carmem', 'Concord' and 'Isabel Precoce' grape cultivars in terms of physicochemical and antioxidant activity of the juices produced.

Sensorially, the extraction methods used did not differ on the overall quality of the juices, except for the juices of 'BRS Carmem' grape cultivar, which 
showed greater appreciation when extracted by the integral suquifier and for 'Bordô' grape cultivar, which was most appreciated when extracted by the adapted heat exchanger method.

\section{ACKNOWLEDGEMENTS}

The authors thank CAPES, FINEP and FAPESC for the financial support and scholarship granted for the development of the experiment and research.

CONFLICTS OF INTEREST: The authors declare no conflict of interest.

\section{REFERENCES}

ABNT-Associação Brasileira de Normas Técnicas, 1993. NBR 12994: análise sensorial dos alimentos e bebidas. Rio de Janeiro.

Bender A., Malgarim M.B., Costa V.B., Silva R.S., Guadagnin V., Andadre S.B. de, 2017. Influência de variedades de uvas Vitis vinifera nas características físico-químicas e na aceitação sensorial do suco. Cienc. Tec. Vitivinic., 32, $213-230$.

Bender A., Souza A.L.K., Caliari V., Malgarin M.B., Andrade S.B., 2018. Perfil físico-químico e sensorial de sucos de uva brancos produzidos por extração a quente. Rev. Elet. Cien. da UERGS, 4, 743-751.

Bender A., Souza A.L.K., Caliari V., Malgarin M.B., Camargo S.S., 2019. Qualidade do suco de uva da variedade Concord Clone 30 elaborado com novo sistema de extração. Rev. Bras. Tecnol. Agroi., 13, 2897 - 2913.

Bender A., Souza A.L.K. de, Caliari V., Malgarin M.B., Costa V.B., Goulart C., 2020. Caracterização físico-química e sensorial de sucos da uva Isabel em cortes com diferentes variedades produzidas na região do Vale do Rio do Peixe-SC. Braz. J. Food Technol., 23, 1-11.

Bender A., Souza A.L.K., Malgarim M.B., Caliari V., Kaltbach P., Costa V.B., 2021. Physicochemical and sensory properties of grape juices produced from different grape cultivars and extraction systems. Semina:Ciencias Agrarias, 42, 1615-1634.

Blouin J., Peynaud É., 2012 Connaissance et travail du vin.. 416 p. Dunod, Malakoff.

Borges R. de S., Prudêncio S.H., Roberto S.R., Assis A.M. de, 2011. Avaliação sensorial de suco de uva cv. isabel em cortes com diferentes cultivares. Rev. Bras. Frut.. 33, 584-591.

Brasil 2018 Instrução Normativa $N^{\circ}$ 14, De 8 De Fevereiro De 2018. Fica estabelecido a complementação dos padrões de indentidade e qualidade do vinho e derivados da uva e do vinho. DOU, 09/03/2018, seção 1, p.4.

Brasil 2005 Ministério da Agricultura, Pecuária e Abastecimento. Instrução Normativa n. 24, de 08 de setembro de 2005: Aprova o manual operacional de bebidas e vinagres.

Brasil 2004 Portaria no 55, de 27 de julho de 2004. Normas referentes à complementação dos padrões de identidade e qualidade do vinho e dos derivados da uva e do vinho. DOU, 30/07/2004, seção 1, p.4.

Brighenti A.F., Allebrandt R., Munhoz B., de Matos D.P., Regina M.A., da Silva A.L., 2018. Qualification of "Bordô" grape clones in Vale do Rio do Peixe, in the state of Santa Catarina, Brazil. Pesq. Agro. Bras., 53, 800-808.

Caliari V. 2018 Uva e vinho. Florianópolis, Epagri/Cepa.111-116p. Epagri, Florianópolis.
Camargo U.A., Maia J.D.G., Ritschel P.S., 2008. BRS Carmem Nova cultivar de uva tardia para suco - Comunicado Técino, 84. 8p. Embrapa Uva e Vinho, Bento Gonçalves.

Dutcosky S.D., 2015. Análise sensorial de alimentos. 540p. Champagnat - Pucpress, Curitiba.

EPAGRI/CIRAM. Monitoramento Climático On-Line. Available at: http://ciram.epagri.sc.gov.br/index.php?option= com_content $\&$ view $=$ article $\&$ id $=98 \&$ Itemid $=198$. $\quad($ accessed on 19.12.2019)

Fadiloglu S., Erkmen O., 2002. Inactivation of lipase by carbon dioxide under atmospheric pressure. J Food Eng., 52, 331-335.

Guerra C.C,, Bitarelo H., Ben L.R, Marin A. 2016. Sistema para elaboração de suco de uva integral em pequenos volumes: suquificador integral - Documentos, 96. 28p. Embrapa Uva e Vinho, Bento Gonçalves.

Kim D-O., Lee K.W., Lee H.J., Lee C.Y., 2002. Vitamin C Equivalent Antioxidant Capacity (VCEAC) of Phenolic Phytochemicals. J. Agric. Food Chem. 50, 3713 - 3717.

Lambri M., Torchio F., Colangelo D., Río Segade S., Giacosa S., De Faveri D.M., Rolle L., 2015. Influence of different berry thermal treatment conditions, grape anthocyanin profile, and skin hardness on the extraction of anthocyanin compounds in the colored grape juice production. Food Res. Int., 77, 584-590.

Leão P.C. de S., Borges R.M.E., 2009. Melhoramento Genético da Videira - Documentos, 224. 64p Embrapa Semiárido, Petrolina.

Lima M.D.S., Dutra M C. P., Toaldo I.M., Corrêa L.C., Pereira G.E., Oliveira D., Bordignon-Luiz-Luiz M. T., Ninow J.L. 2015. Phenolic compounds, organic acids and antioxidant activity of grape juices produced in industrial scale by different processes of maceration. Food Chem, 188, 384-392.

Maldonade I.R, Carvalho P.G.B., Ferreira N.A., 2013. Protocolo para determinação de açúcares totais em hortaliças pelo método de DNS - Comunicado Técnico, 85. 3p. Embrapa Hortaliças, Brasília.

Marcon Â.R., Dutra S.V., Roani C.A., Spinelli F.R., Leonardelli S., Venturin L., Vanderlinde R. 2016. Avaliação da incorporação de água exógena em sucos de uva elaborados por panela extratora. Revista Brasileira de Viticultura e Enologia, 8, 52-57.

McGuire R.G., 1992. Reporting of Objective Color Measurements. HortScience 27, 1254-1255.

Nodari E.S., Frank Z., 2019. Vinhos de Altitude no Estado de Santa Catarina: a firmação de uma identidade. Rev. Tempo $e$ Argum. 11, 183-200.

OIV - Organisation Internationale de la Vigne et du Vin, 2009. Recueil des Méthodes Internationales d'Analyse des Vins et des Moûts. 368p. Organisation Internationale de la Vigne et du Vin, Paris.

Pontes P.R.B., Santiago S.S., Szabo T.N., Toledo L.P., Gollücke A.P.B., 2010. Atributos sensoriais e aceitação de sucos de uva comerciais. Ciênc. Tecnol. Aliment., 30, 313-318.

Santana M.T.A., Siqueira H.H. de, Reis K.C. dos, Lima L.C. de O., Silva R.J.L., 2008. Caracterização de diferentes marcas de sucos de uva comercializados em duas regiões do Brasil. Ciên. Agrotec .32, 882-886.

Silva M.J. da R., da Silva Padilha C.V., dos Santos Lima M., Pereira G.E., Filho W.G.V., Moura M.F., Tecchio M.A., 2019a. Grape juices produced from new hybrid varieties grown on Brazilian rootstocks - Bioactive compounds, organic acids and antioxidant capacity. Food Chem., 289, 714-722. 
Silva G.G., Nascimento R.L., Oliveira V.D.S., Araújo A.J. de B, Oliveira J.B., Pereira G.E., 2011. Características físico-químicas de sucos de uvas 'Isabel Precoce' e 'BRS Violeta' elaborados no Nordeste do Brasil. In: An. da $6^{a}$ Jorn. Iniciação Científica da Embrapa Semiárido. Brasília, Brasil.

Silva H.A., Nascimento A.S., Alcântara V.M., Alcântara V.H. Barros S.L., 2019b. Avaliação físico-química de sucos de uvas concentrados. Rev. Craib. Agroeco. 4, e-7660.

Singleton V.L., Rossi J.A., 1965. Colorimetry of total phenolics with phosphomolybdic-phosphotungstic acid reagents. Am. J. Enol. Vitic. 16, 144-158.

Teixeira L.V., 2009. Análise sensorial na indústria de alimentos. Rev. Inst. Lat. Cândido Tostes 64, 12-21.
Toaldo I.M., de Gois J.S., Fogolari O., Hamann D., Borges D.L.G., Bordignon-Luiz M.T., 2014. Phytochemical Polyphenol Extraction and Elemental Composition of Vitis labrusca L. Grape Juices Through Optimization of Pectinolytic Activity. Food Bioproc Tech., 7, 2581-2594.

UVIBRA. Comercialização de vinhos e derivados elaborados no RS de 2012 á 2018 - Mercado interno e externo. Available at: http://www.uvibra.com.br/pdf/comercializacao2012a2018 _dez.pdf. (accessed on 19.10.2021).

Wrolstad R.E., 1993. Color and Pigment Analyses in Fruit Products. Station Bulletin 624. Corvallis: Oregon Agricultural Experimental Station.

Zanus M.C., 201. Panorama da Vitivinicultura brasileira. In: $V$ Congresso Latino-americano de Viticultura e Enologia XIII Congresso Brasileiro de Viticultura e Enologia. Bento Gonçalves, Brasil . 